DOI https://doi.org/10.30525/978-9934-588-46-4.15

\title{
MECHANISMS OF STATE ADMINISTRATION \\ BY THE MIGRATION POLICY OF UKRAINE IN THE CONTEXT OF EUROPEAN INTEGRATION AND GLOBALIZATION CHALLENGES
}

\section{Tkachova N. M., Kazanska O. O.}

\section{INTRODUCTION}

Currently, one of the challenges for many states and for Ukraine in particular is illegal migration, which has an impact on the security of the state and its international relations. Due to its geopolitical location, Ukraine has become not only a transit zone on the way of migration flows towards the countries of Western Europe but is gradually becoming a country of long-term stay of illegal migrants.

Having chosen the course for Euro-Atlantic integration, Ukraine has undertaken international commitments in order to implement an effective and preventive policy on combating illegal migration, to take measures to strengthen control over the stay of foreigners on the territory of the country, and to introduce effective administrative coercion against violators of migration law.

The process of formation and implementation of the national security state policy currently is one of the most acute issue in Ukraine. Modern realities of Ukraine's existence as an independent state require, within the framework of the national security policy implementation, to take into account the country's request to realize national interests in all spheres of society's life. Nowadays, the country faces intensification of the unregulated (illegal) migration processes and the lack of an effective state regulation system of migration processes, which constitute a direct threat to the country national security, promote the criminalization growth and the organized criminal groups' formation, and contribute to the social tension exacerbation in society. The bodies of the State Migration Service (SMS) of Ukraine face with an urgent need for a more profound migration perception as a socio-economic phenomenon and an active search for qualitatively new approaches to migration policy formation and control over population territorial movements. 
Due to the fact that Ukraine is at the same time a country of origin, destination and transit of migrants, territory of diverse, multidirectional and of different scales migratory flows, ensuring state regulation in the field of migration is a complex task, the solution of which requires an integrated, systematic approach, adequate funding, personnel and scientific support; the tasks and the goals in this area are prioritized, determined and regulated by the Strategy of the State Migration Policy of Ukraine for the period up to 2025 .

\section{Illegal migration in Ukraine. Analysis of the state}

Due to the fact that Ukraine is at the same time a country of origin, destination and transit of migrants, territory of diverse, multidirectional and of different scales migratory flows, ensuring state regulation in the field of migration is a complex task, the solution of which requires an integrated, systematic approach, adequate funding, personnel and scientific support; the tasks and the goals in this area are prioritized, determined and regulated by the Strategy of the State Migration Policy of Ukraine for the period up to 2025.

At present, according to expert estimates, 257 thousand migrants are permanently resident in Ukraine. These are people who are offenders in one way or another: they either have a delayed visa, or just an illegal stay in Ukraine, an overdue 90-day period, or a violation of the rules of stay. At the same time, if the belongingness of illegal migrants to the citizenship of one or another country cannot be identified, they are placed in special detention centres for foreigners. Among the countries with the biggest numbers of migration law violators, the former republic of the USSR (Moldova, Russia, Georgia, and Azerbaijan) as well as more distant countries with a low standard of living, such as Vietnam, Afghanistan, and Bangladesh take the leading positions.

According to statistics, about $70 \%$ of illegal migrants are men aged 20 to 40 years old. Some of them have a low educational level, a low professional qualification associated with the use of hard physical labour, but most are usually unemployed and persons without certain occupations. A particular danger is caused by the fact that the majority of illegal migrants arrives in Ukraine from countries where various terrorist organizations are active. It leads not only to the criminal situation deterioration, but also to direct political, social complications and causes economic damage to the state, indicating a high degree of social danger.

It ought to be noted that a large group of foreigners illegally staying in Ukraine destabilizes the socio-economic situation. According to expert 
estimates, each illegal costs the country about 600-800 USD per annum, even if the person lives in cities without receiving any social assistance from the state, because he/she consumes a national product, uses social benefits created by labour and at the expense of taxes paid by the local population, with virtually no reimbursement.

Thus, unregulated foreigners and person destitute of nationality migration through Ukraine has become part of the overall migration process. Beginning in 2015, there has been a tendency for a large number of illegal migrants to be detected within the state and at its borders.

According to the statistics of the State Migration Service of Ukraine in 2016, 6.390 illegal migrants were identified, about 5.729 people made a decision on refoulement from the territory of Ukraine, executed decisions on refoulement from the territory of Ukraine was 2.092 cases; in 2017 there were 9.678 illegal migrants identified, about 9.264 people made a decision on refoulement from the territory of Ukraine, executed decisions on refoulement from the territory of Ukraine was $4.415^{1}$.

It is essential that the terms "illegal migration" and "illegitimate migration" in the scientific literature are usually used synonymously. However, there is a difference between them regarding the sphere of use: the term "illegitimate migration" is most often used in official documents, while the notion of "illegal migration" is more characteristic of scientific research and journalistic texts ${ }^{2}$.

In the official terminology of the United Nations, instead of the term "illegal migration", the term "irregular migration" is predominantly used; instead of the term "illegal migrant" there is an "irregular migrant" or a "foreigner without proper documents" (undocumented migrant or alien). This approach reflects the humanistic perception of the illegal migration phenomenon in the modern world, in view of the need to respect human rights and the prohibition of discrimination; it is based on the personal freedom and inviolability principle, freedom of movement, freedom of residence choice, etc.

1 Statistics on main activity. State Migration Service of Ukraine. URL: https://dmsu.gov.ua/diyalnist/statistichni-dani/statistika-z-osnovnoj-diyalnosti.html (Last accessed: 03.03.2020).

${ }^{2}$ Romanyuk M. Migration of the Ukrainian population in a transition economy. Methodology and practice of regulation. Lviv : World, 1999. P. 126.

${ }^{3}$ International Migration Law: glossary on Migration / International Organization for Migration, 2004. 78 p. URL: www.demoscope.ru/weekly/2004/0183/biblio06.php (Last accessed: 03.03.2020) 
However, unlike international law, in national legislation, the EU Member States in most cases tend to prioritize the security and economic interests of the state, which is in direct conflict with the human right to freedom of movement and residence, with some degree of discriminatory character. Thus, in the vast majority of the EU legal documents, in particular in the "Common Policy on Counteraction to Illegal Immigration", the term "illegal immigration" is used and is defined as illegal entry and stay of persons in the member countries.

In accordance with this act illegal migration takes place based on the following: a foreigner from one of the EU member states crosses the frontier with falsified (forged) papers or with the absence of an official permit for staying in the country; in case of a delay in the validity of the residence permit after authorized entry; in case when a person works or is engaged in entrepreneurial activity; if it is forbidden by an entry visa or a residence permit ${ }^{4}$.

Taking into consideration the socio-economic situation, at the present time the migration attractiveness of Ukraine is relatively low compared to other countries that host migrants. Due to a number of factors, so far, Ukraine has not become a transit country for migrants who travel to the EU. As a result, the number of migrants arriving in Ukraine has decreased in Donbass area and because of the Crimea annexation. The security reasons and the instability of the economic situation through military actions have prevented the migrant flow to Ukraine.

However, the exacerbation of the socio-political situation in several countries in the Middle East, Asia and North Africa and the escalation of conflicts have led to a significant increase in illegal migrants moving to the EU.

People, who have previously attempted to enter through the territory of Russia via unregulated way, and then through Ukraine get into the EU, today, at least, have very serious obstacles on their way: both because of the conflict in the East and military actions, and because of the fact that the western border of Ukraine in recent years has significantly strengthened. At the same time, the general migration crisis in the European Union countries, the targeted actions of the European Union member states, regarding the migration flows settlement and taking measures to establish restrictions on entry into its territory,

\footnotetext{
${ }^{4}$ Palagniuk O. Analysis of the mechanisms of state regulation of illegal migration in Ukraine in the modern researchers' writings. Public Administration and Local Self-Government, 2014. Issue 1 (20). Pp. 83-92. 
including through the border crossing, gives grounds to assert that in the near future Ukraine may face the need to react quickly and flexibly to the growth of the migratory flow intensity.

According to Article 1 of the Law of Ukraine "On National Security of Ukraine" state security is defined as the protection of state sovereignty, territorial integrity and democratic constitutional order and other vital national interests from real and potential threats of nonmilitary character; threats to the national security of Ukraine phenomena, tendencies and factors that contradict the national interests and national values of Ukraine; national security of Ukraine - protection of state sovereignty, territorial integrity, democratic constitutional order and other national interests of Ukraine against real and potential threats; national interests of Ukraine are vital interests of the person, society and the state and safe living conditions and well-being of its citizens ${ }^{5}$.

\section{Mechanisms of state administration by the migration policy}

It is generally known that any phenomenon or process is not practical without an active mechanism for their implementation. The interaction of SMS with state authorities is also a mechanism. Moreover, it is a dynamic phenomenon, which depends on the way it functions, i.e. the mechanism of implementation.

In the scientific literature, the term "management mechanism" is widely used, but its content and structure are interpreted differently by various scholars and practitioners. The most widespread definition is given by B. Bakumenko, V. Knyazev: the mechanisms of state administration are "practical measures, means, and levers, incentives through which public authorities influence society, production, and any social system in order to achieve set goals". The integrated mechanism of public administration is defined as "a system of political, economic, social, organizational and legal means of purposeful influence of public administration". The scheme of the real mechanism of government includes: goals, decisions, influences, actions, result ${ }^{6}$.

${ }^{5}$ On the national security of Ukraine : Law of Ukraine dated 21.06.2018 No. 2469-III. Verkhovna Rada of Ukraine. URL: http://zakon.rada.gov.ua/ laws/show/2469-19 (Last accessed: 03.03.2020).

${ }^{6}$ Public administration: Dictionary / Directory: V. Bakumenko (head of ed..), D. Beznosenko, I. Varzar, V. Knyazev, S. Kravchenko, L. Bayonet; Ed. by V. Knyazev, V. Bakumenko. Kyiv : Publishing House "Ukrainian Academy of Public Administration", 2002. P. 63. 
In authors' opinion, the mechanism of interaction of SMS with state authorities and local self-government is a single integrated regulator aimed at preventing illegal migration, transnational crime by coordinating activities and establishing clear interaction between the State Migration Service and public authorities. Since any mechanism is a system with a high degree of organization, and each system has its own structure, one can talk of the mechanism structure of SMS interaction with state authorities in the field of counteracting illegal (illegitimate) migration.

The definition of "organization" in the context of the being investigated issue, can be used in two ways: 1) as one of the most important elements of the SMS interaction mechanism in the counteraction to illegal migration sphere, which is embodied in the influence on the process of this interaction in order to structure it; 2) as the desired end result of such influence, in the form of a qualitatively new level of coherence in activity.

The SMS interaction with public authorities and local selfgovernment is manifested in their joint activity, which is carried out within the framework of the system. In accordance with the Decree of the Cabinet of Ministers of August 20" , 2014, No. 360 "On Approval of the Regulation on the State Migration Service of Ukraine", the SMS while carrying out its tasks interacts in accordance with the established procedure, with other state bodies, subsidiary bodies and services established by the President of Ukraine, local self-government bodies, public unions, trade unions and employers' organizations, relevant bodies of foreign states and international organizations, as well as enterprises, institutions and organizations. Thus, in the process of organizing this interaction, the SMS subdivisions systematically coordinate and synchronize their activities with the departments of ministries and services, state executive bodies and local self-government bodies.

Regarding the hierarchical structure of the SMS, the indicated interaction is carried out at the levels, which implies the presence of its appropriate organization.

The national level involves the organization and implementation of existing cooperation between relevant state and non-state bodies of Ukraine. As the subjects of interaction there are the SMS and the bodies of state executive power (SSU, National Police, SMS, the patrol and inspection service, etc.). The regional level has its multilevel structure, which is determined by the authority bodies that take organizational 
decisions and communicate at the regional level, namely: heads of regional departments of the Ministry of Internal Affairs, Ministry of Internal Affairs, State Tax Administration, heads of regional state administrations, local authorities of public authority within their competence.

The main requirements that are put forward to the required level of organization of this interaction are: reliability and rationality of interaction; its effectiveness; saving of forces and means; clarity and promptness (timeliness) of interaction actions; maintaining the interaction of the organizational subject structure within this organization $^{7}$.

The main normative acts regulating the authorities' interaction with regard to preventing and counteracting illegal migration are:

- procedure for carrying out measures to oversee and control the legislation implementation in the field of migration, approved by Order No. 850/536/1226 of 04.09.2013 of the Ministry of Internal Affairs of Ukraine, Ministry of Social Policy of Ukraine and the Ministry of Education and Science of Ukraine; however, this procedure only determines the purpose of the measures and indicates which departments are involved in carrying out preventive measures;

-instruction on compulsory return and forced removal from Ukraine of foreigners and stateless persons, approved by the order No 353/271/150 dated April 23 $3^{\text {rd }}, 2012$, of the Ministry of Internal Affairs of Ukraine, the Administration of the State Border Guard Service of Ukraine, the Security Service of Ukraine, which approves the procedure of territorial bodies officials, SMS territorial subdivisions, state border guard institutions and the SSU bodies during the decision-making on the forced return and initiation of decisions on the forced removal of foreigners from Ukraine.

However, in the above-mentioned instruction, there is no mechanism for cooperation between authorities in countering illegal migration.

The analysis of the foreign countries experience in combating organized crime shows that in world law enforcement practice, illegal migration is defined as a generally recognized form of organized crime, the opposition of which from the relevant national structures is becoming increasingly relevant.

${ }^{7}$ Kolpakov V., Kuzmenko O. Administrative Law of Ukraine. Kyiv : Yurinkom Inter, 2003. P. 3. 
As a rule, foreigners who are released from prison, do not leave the territory of Ukraine; they are recidivists who are repeatedly convicted and who do not have grounds to legally reside on the territory of Ukraine; they are involved in the illegal migration and crime situation in the country. It is almost impossible to make a decision in court against Forced release of this category of foreigners without prior compulsory return.

It has to be considered that for the first time in the national scientific thought the study of the mechanism of counteraction to illegal migration from the point of view of administrative law was proposed by O. Kuzmenko, who determined the administrative-legal mechanism of counteraction to illegal migration contains the following elements: a system of legal acts; organizational and structural mechanism formation (that is, actors who carry out counteraction); organizational and legal methods (i.e., types of activities of counteraction actors). V. Kolpakov pays attention to the mechanism of ensuring the legal regime as an integral part of the rule of law adherence, which includes: organizational and structural formations and organizational and legal methods ${ }^{8}$.

According to existing firm views, the migration policy in Ukraine is a system of legal, financial, administrative and organizational measures of the state and non-state institutions on the migration processes regulation from the standpoint of migration priorities, quantitative and qualitative migration flows structure, their social, demographic and economic structure ${ }^{9}$.

The leading domestic researcher $\mathrm{V}$. Moiseenko studies migration policy as the state influence on migration processes through their direct regulation ${ }^{10}$.

A. Khomra, in turn, gives the following definition: "migration policy is a complex of developments and measures aimed at forming the necessary flows and the required intensity of population migration" ${ }^{11}$.

${ }^{8}$ Kolpakov V., Kuzmenko O. Administrative Law of Ukraine. Kyiv : Yurinkom Inter, 2003. P. 3.

${ }^{9}$ Palagniuk O. Analysis of the mechanisms of state regulation of illegal migration in Ukraine in the modern researchers' writings. Public Administration and Local Self-Government, 2014. Issue 1 (20). Pp. 83-92.

${ }^{10}$ Moiseenko V. Actual Issues of Migration Policy in the USSR. Problems of Demographic Policy in Socialist Society : Thesis. All Union. conf. Moskva, 1982. P. 27.

${ }^{11}$ Khomra A. Population Migration: Theory, Research Methods. Kyiv : Scientific opinion, 1979. P. 112. 
According to T. Petrova, "migration policy is a system of legal, financial, administrative and organizational measures of the state and non-state institutions on the regulation of migration processes from the standpoint of migration priorities, quantitative and qualitative structure of migration flows, their social, demographic and economic structure" ${ }^{12}$.

It should be noted that the majority of researchers in the field of migration processes study usually use the term "migration regime", which is understood as the administrative and legal regime, in which the regulation of migration flows and prevention of illegal entry of foreigners into the territory of Ukraine are carried out.

Establishing and maintaining the migration regime effectiveness is ensured through various mechanisms, among which, the most effective mechanism is the counteraction to illegal migration. Thus, it includes the following elements:

1) the system of normative legal acts, which form the basis of the mechanism functioning;

2) organizational and structural mechanism formation;

3) organizational and legal ways of illegal migration counteracting ${ }^{13}$.

The Resolution of the Cabinet of Ministers of Ukraine dated July $12^{\text {th }}$, 2017, No. 482-p approved the Strategy of the State Migration Policy of Ukraine for the period up to 2025, where one of the goals is to strengthen control over the migration legislation observance within the country. It is also determined that the intensity and types of interventions ought to be proportionate to the risks of illegal migration and the possible threats that lead to such violations.

In authors' opinion, the mechanism of interaction of SMS with state authorities and local self-government is a single integrated regulator aimed at preventing illegal migration, transnational crime by coordinating activities and establishing clear interaction between the State Migration Service and public authorities. Since any mechanism is a system with a high degree of organization, and each system has its own structure, one can talk of the mechanism structure of SMS interaction with state authorities in the field of counteracting illegal (illegitimate) migration.

12 Petrova T. Conception of the State Migration Policy of Ukraine: Target Orientation and Main Directions. Kyiv, 1991. P. 2.

${ }^{13}$ Serova I. Theoretical and conceptual issues of international legal definition of illegal migration and mechanisms of this phenomenon counteraction. Juridical journal. 2006. No. 3. Pp. 16-21. 
This mechanism includes the organization of interaction and the process of this interaction itself. Y. Galaniuk identifies two components in the structure of this mechanism, i.e. organizational and activity. In order to designate them, it is most expedient to use the "organization of interaction" and "implementation of interaction" categories ${ }^{14}$. The definition of "organization", in the context of the being investigated issue, can be used in two ways: 1) as one of the most important elements of the SMS interaction mechanism in the counteraction to illegal migration sphere, which is embodied in the influence on the process of this interaction in order to structure it; 2) as the desired end result of such influence, in the form of a qualitatively new level of coherence in activity.

Authorities of state control over compliance with legislation in the areas of migration (immigration and emigration), counteracting illegal (irregular) migration, including bringing violators to administrative responsibility for violation of the rules of stay on the territory of Ukraine, violation of the order of employment and assistance in providing other services to the State Migration Service of Ukraine (SMS).

The need to create a single migration authority in Ukraine was first discussed in Europe. For example, the EU-Ukraine Action Plan "European Neighbourhood Policy" envisaged the creation of a single state authority on migration policy ${ }^{15}$.

The State Migration Service of Ukraine is one of the youngest authorities to take over the functions of the Ministry of Internal Affairs for Citizenship, Migration and Registration of Persons and has been eliminated in the process of reforming the functions of the State Committee on Nationalities and Religions for the Protection of Refugees. In 2011, Presidential Decree No. 405/2011 approved the Regulation on the State Migration Service of Ukraine, which defined the main tasks, functions and powers of the SMS.

In 2012, in order to ensure the implementation of the tasks set by the SMS on the embodiment of state policy in the area of combating illegal migration, the Ministry of Internal Affairs established the Office of

${ }^{14}$ Galanyuk Ya. Improvement of mechanisms of interaction of the state border service of Ukraine with state authorities and local self-government. Proceedings of Tavria National University after V. Vernadsky. Series: Public Administration, Vol. 29 (68) No. 1, 2018, p. 48.

15 The Law of Ukraine "On the Legal Status of Foreigners and Stateless Persons". Bulletin of the Verkhovna Rada of Ukraine, 2012, No. 19-20, p. 179. 
Migration Control Police with a total limit of 1500 units, which was liquidated at the end of the same year.

Following the elimination of migration control units, the Government has not resolved the issue of legislative and organizational issues in combating illegal migration. The SMS of Ukraine, lacking adequate means and forces, was not actually able to fully ensure the function of controlling the stay of foreigners in the territory of Ukraine and taking relatively effective administrative measures.

In 2014, a new Regulation on the SMS was approved, according to which the SMS is the central executive body, the activity of which is directed and coordinated by the Cabinet of Ministers of Ukraine advocated through the Minister of the Interior. In accordance with the assigned tasks, the SMS provides measures to prevent and counter illegal (irregular) migration, other violations of migration legislation and perform law enforcement functions within the authority. Moreover, in order to ensure the fulfilment of its tasks, the SMS was granted the right to initiate joint inspections with law enforcement and other central executive authorities within the powers provided for by law.

As of the end of 2019, the task of preventing and combating illegal (irregular) migration is entrusted to the Office for Foreigners and Stateless Persons of the SMS, departments and sectors of the organization for the prevention of illegal migration, readmission and elimination of SMS in the regions, which comprises a total of 30 structural units with a staffing of 216 units.

A major positive result in the implementation of measures to prevent and counteract illegal (irregular) migration was the conduct of preventive measures in the territory of the state under the conditional name "Migrant" with the involvement of the National Police, State Border Service and Security Service of Ukraine and other authorities. As a result, in 2016, the following was revealed: 1544 illegal migrants (in 2017 - 5 515; in 2018 - 5 554), compared to 1381 persons made a decision on forced return outside Ukraine (in 2017 - 5 073; in 2018 5 114), 60 persons (in 2017 - 211, in 2018 - 420) were forcibly expelled from Ukraine, 54 (in 2017 - 152, in 2018 - 347) foreigners were accommodated in the places of temporary residence of foreigners and stateless persons, 200 (in 2017 - 1 089, in 2018 - 1 358) foreigners are prohibited from entering Ukraine ${ }^{16}$.

\footnotetext{
${ }^{16}$ State Migration Service of Ukraine. URL: https:/goo.gl/aaoBik (Last accessed: 03.03.2020).
} 
The extent to state control over the observance of the legislation on labour and use of work of foreigners and stateless persons is vested in the State Labour Service of Ukraine, which is the central body of executive power, the activity of which is directed and coordinated by the Cabinet of Ministers of Ukraine through the Minister of Social Policy.

The State Employment Service (hereinafter referred to as "the Service"), which is a centralized system of state institutions, whose activity is directed and coordinated by the Ministry of Social Policy of Ukraine, is authorized to issue permits for the use of work of foreigners and stateless persons and to continue its validity.

According to the Risk Analysis Methodology to Combat Illegal Migration, only the exchange of statistical and analytical information between the Subjects, in particular, the State Migration Service of Ukraine and the Ministry of Social Policy of Ukraine regarding the number of issued, extended and revoked permits for the use of foreigners and stateless persons is presupposed. Granting a visa-free regime to Ukraine requires from the bodies of the State Migration Service and the Ministry of Social Policy not only the exchange of information but also the improvement of the mechanism of interaction and cooperation regarding foreigners and stateless persons who can thus legalize their temporary stay in Ukraine.

According to the United Nations Migration Agency, as of August 2018, 9836000 foreigners and stateless persons are being registered for employment in Ukraine. Most foreigners and stateless persons who resided in Ukraine for employment purposes as of August 2018 were citizens of Turkey (1 688), Russia (1 209), Belarus (599), China (543), Azerbaijan (490), USA (439) and Israel (342). At the same time, most of these persons are registered in the city of Kyiv $-51 \%$, in Kyiv region $14 \%$, in Lviv region $-6.3 \%$ and in Odesa region $-6.3 \%$.

According to the Migration Monitoring and Changes in Immigration and Border Management, as of August 2018, 4544 temporary residence permits in Ukraine were issued for employment by territorial bodies of the State Migration Service and 1665 (temporary) were renewed ${ }^{17}$.

According to Article 42-2 of the Law of Ukraine "On Employment of the Population" of 05 July 2012, to obtain a permit for the use of work of foreigners and stateless persons and to continue its validity it is necessary

${ }^{17}$ Galaniuk O. Analysis of mechanisms of state regulation of illegal migration in Ukraine in the works of modern researchers. State Administration and Local SelfGovernment, 2014. Issue 1 (20). Pp. 83-92. 
to submit: an application, a copy of the passport document, photos, a copy of the draft employment contract with a foreigner or a stateless person. It should be noted that, as of November 2017, pursuant to the Decree of the Cabinet of Ministers of Ukraine No. 858 of November 15, 2017 , in order to receive a work permit for foreigners and stateless persons, which grants the right to obtain a temporary residence permit in Ukraine, checks on the foreign nationals being brought to administrative or criminal responsibility in Ukraine, the opening of criminal proceedings against them, the presence or absence of criminal convictions in the country of origin, and the carrying out of medical examination for the presence of such disease as chronic alcoholism, substance abuse, drug abuse or other infectious diseases specified by the Ministry of Health will not be included in application. The citizens of the Russian Federation, the aggressor country that is a migrant risk country, have a visa-free regime with Ukraine. Russian citizens are not obliged to obtain a temporary residence permit in Ukraine for employment purposes. In addition, the legislation of Ukraine does not have a normative document that would provide a mechanism for interaction of the State Migration Service bodies with the bodies of the State Employment Centre, to establish the fact of using the work of a foreigner or a stateless person under conditions other than those specified by the permit or by another employer.

One such administrative coercion that applies to foreigners and stateless persons is "forced expulsion". In the legislation of Ukraine, "forced expulsion" is considered as a procedure of physical expulsion from the country by a court decision issued on the claim of the relevant executive authorities. The term "forced expulsion" means a system of administrative and legal measures aimed at forcing foreigners who are illegally staying in Ukraine to leave the territory of Ukraine contrary to their will and desire.

Article 30 of the Law of Ukraine "On the Legal Status of Aliens and Stateless Persons" of September 22, 2011, No. 3773-VI determined that forcible removal of a foreigner or stateless person is possible only on the basis of a decision of an administrative court issued by an administrative lawsuit of the SMS, protection of the state border and the Security Service of Ukraine in the following reasons: if the foreigner or stateless person failed to execute the decision on compulsory return in due time without valid reasons; if there are reasonable grounds for believing that a foreigner or stateless person will evade the execution of such a decision, except in cases of detention of a foreigner or stateless person for illegally 
crossing the state border of Ukraine outside the border crossing points of Ukraine and transferring them to the border authorities of a neighbouring state.

It is an instructive experience to apply measures of administrative coercion in the neighbouring Republic of Poland, where according to Article 302 and Article 319 the foreigner is not allowed to enter the EU. In particular, a foreigner is prohibited from entering the country from six months to three years if the period of stay in the country is exceeded; sentenced to imprisonment in Poland and there are grounds for carrying out proceedings for his/her transfer abroad for the purpose of punishment - entry from one year to three years is forbidden; the person cannot stay in Poland for reasons of defence or security of the state or for the protection of security and public order - entry into the country for a period of five years is prohibited. In addition, the main way of return from the territory of the Republic of Poland is a "forced obligation" which is exercised independently and at own expense ${ }^{18}$.

\section{CONCLUSIONS}

Therefore, illegal migration remains a threat to national security and public order and is recognized by scientists and practitioners as a complex public policy area, consisting of a number of interconnected components that are the responsibility of various public authorities.

\section{SUMMARY}

Illegal migration is one of the main real and potential threats to the national security of Ukraine, stability in society. Today, the country faces intensification of the processes of unregulated (illegal) migration and the lack of an effective system of state regulation of migration processes, which constitute a direct threat to the national security of the country, promote the growth of criminalization and the formation of organized criminal groups, contribute to the exacerbation of social tension in society. So, the State Migration Service of Ukraine faces with an urgent need for a deeper understanding of migration as a socio-economic phenomenon, the search for qualitatively new approaches to the

${ }^{18}$ ISAP - Internet system of legal acts ISAP - legal acts and other documents of the Polish authorities in emigration. USTAWA o cudzoziemcach 1), 2) z dnia 12 grudnia 2013 r. URL: http://prawo.sejm.gov.pl/isap.Nsf/download.xsp/ WDU20130001650/T/D20131650L.pdf (Last accessed: 03.03.2020). 
formation of migration policy and control over the territorial movement of the population.

The article considers modern approaches to the concept definition of "illegal migration" and accents the need to improve the processes of interaction between authorities in order to reduce the negative impact of illegal migration processes on the socio-political and economic life of the country in the context of European integration.

\section{REFERENCES}

1. Statistics on main activity. State Migration Service of Ukraine. URL: https://dmsu.gov.ua/diyalnist/statistichnidani/statistika-z-osnovnoj.diyalnosti.html (Last accessed: 03.03.2020)

2. Romanyuk M. Migration of the Ukrainian population in a transition economy. Methodology and practice of regulation. Lviv : World, 1999. 292 p.

3. Galaniuk O. Analysis of mechanisms of state regulation of illegal migration in Ukraine in the works of modern researchers. State Administration and Local Self-Government, 2014. Issue 1 (20). Pp. 83-92.

4. Palagniuk O. Analysis of the mechanisms of state regulation of illegal migration in Ukraine in the modern researchers' writings. Public Administration and Local Self-Government, 2014. Issue 1 (20). Pp. 8392.

5. On the national security of Ukraine : Law of Ukraine dated 21.06.2018 No. 2469-III. / Verkhovna Rada of Ukraine. URL: http://zakon.rada.gov.ua/laws/show/2469-19 (Last accessed: 03.03.2020).

6. Public administration: Dictionary / Directory: V. Bakumenko (head of ed..), D. Beznosenko, I. Varzar, V. Knyazev, S. Kravchenko, L. Bayonet; Ed. by V. Knyazev, V. Bakumenko. Kyiv : Publishing House "Ukrainian Academy of Public Administration", 2002. 228 p.

7. Galanyuk Ya. Improvement of mechanisms of interaction of the state border service of Ukraine with state authorities and local selfgovernment. Proceedings of Tavria National University after V. Vernadsky. Series: Public Administration, Vol. 29 (68) No. 1, 2018, pp. 47-53.

8. Kolpakov V., Kuzmenko O. Administrative Law of Ukraine. Kyiv : Yurinkom Inter, 2003. 544 p. 
9. Moiseenko V. Actual Issues of Migration Policy in the USSR. Problems of Demographic Policy in Socialist Society : Thesis. All Union. conf. Moskva, 1982. 119 p.

10. Khomra A. Population Migration: Theory, Research Methods. Kyiv : Scientific opinion, 1979. 146 p.

11. Petrova T. Conception of the State Migration Policy of Ukraine: Target Orientation and Main Directions. Kyiv, 1991. P. 27.

12. Serova I. Theoretical and conceptual issues of international legal definition of illegal migration and mechanisms of this phenomenon counteraction. Juridical journal. 2006. No. 3. Pp. 16-21.

13. The Law of Ukraine "On the Legal Status of Foreigners and Stateless Persons". Bulletin of the Verkhovna Rada of Ukraine, 2012, No. 19-20, p. 179.

14. State Migration Service of Ukraine. URL: https://goo.gl/aaoBik (Last accessed: 03.03.2020).

15. ISAP - Internet system of legal acts ISAP - legal acts and other documents of the Polish authorities in emigration. USTAWA 0 cudzoziemcach 1), 2) $\mathrm{z}$ dnia 12 grudnia 2013 r. URL: http://prawo.sejm.gov.pl/isap.Nsf/download.xsp/WDU20130001650/ T/D20131650L.pdf (Last accessed: 03.03.2020).

\section{Information about authors:} Tkachova N. M.,

Doctor of Sciences in Public Administration, Professor, Head of the Department of Information and Communication

Technologies of Business Education National Aviation University 1, ave. Lubomir Husar, Kyiv, 103058, Ukraine

Kazanska O. O.,

Candidate of Sciences in Public Administration, Associate Professor of the Department of Information and Communication Technologies of Business Education

National Aviation University 1, ave. Lubomir Husar, Kyiv, 103058, Ukraine 